Edubiotik: Jurnal Pendidikan, Biologi dan Terapan

ISSN 2528-679X (print), ISSN 2597-9833 (online)

Volume 4, Nomor 02, Tahun 2019, Hal. 83 - 92

Available online at:

http://ejurnal.budiutomomalang.ac.id/index.php/edubiotik

\title{
Identifikasi tumbuhan dalam masakan tradisional urap-urap sebagai materi penyusunan buku referensi taksonomi tumbuhan
}

\author{
Mucharommah Sartika Ami, Evi Ayu Candra
}

Pendidikan Biologi, Universitas KH. A. Wahab Hasbullah, Jombang, Indonesia

E-mail: sartika.ami@gmail.com*, evi.ayucandra88@gmail.com

\begin{tabular}{|c|c|}
\hline Informasi Artikel & ABSTRACT \\
\hline $\begin{array}{l}\text { Submit: } \\
17-07-2019 \\
\text { Diterima: } \\
21-08-2019 \\
\text { Dipublikasikan: } \\
01-09-2019\end{array}$ & $\begin{array}{l}\text { One of the conservation efforts that needs to be implemented is plant } \\
\text { exploration activities as local wisdom. There are various forms of local } \\
\text { wisdom and one of them is traditional cuisine. This study aims to identify the } \\
\text { types of plants used in traditional East Javanese cuisine, namely urap-urap. } \\
\text { The types of plants that were identified obtained from the interview to the } \\
\text { informant using an interview guide. Plant identification is done through direct } \\
\text { observation using the observation sheet and the results compared with a } \\
\text { reference scientific identification. Data were analyzed by descriptive } \\
\text { qualitative. The results showed that there were } 13 \text { types of plants identified in } \\
\text { traditional cuisine namely urap-urap, four types including the } \\
\text { Monocotyledonae class and nine other types were members of the } \\
\text { Dicotyledonae class. The } 13 \text { types of plants include Allium cepa, Allium } \\
\text { sativum, Capsicum anum, Capsicum frutescens, Citrus hystrix, Vigna } \\
\text { radiata, Vigna sinensis, Ipomoea reptans, Cocos nucifera, Ocimum sanctum, } \\
\text { Caempferia galanga, Cucumis sativus, and Caricaaya. This research } \\
\text { concludes that } 13 \text { types of plants have been identified in traditional Javanese } \\
\text { ointment which is Monocotyledonae and Dicotyledonae classes. } \\
\text { Key words: Plant taxonomy, Traditional cuisine }\end{array}$ \\
\hline Penerbit & ABSTRAK \\
\hline $\begin{array}{l}\text { Program Studi } \\
\text { Pendidikan Biologi, } \\
\text { Fakultas Pendidikan } \\
\text { Ilmu Eksakta dan } \\
\text { Keolahragaan, IKIP } \\
\text { Budi Utomo, Malang, } \\
\text { Indonesia }\end{array}$ & $\begin{array}{l}\text { Salah satu upaya konservasi yang perlu dilaksanakan adalah kegiatan } \\
\text { eksplorasi tumbuhan sebagai kearifan lokal. Ada berbagai macam bentuk } \\
\text { kearifan lokal dan satu di antaranya adalah masakan tradisional. Penelitian ini } \\
\text { bertujuan untuk mengidentifikasi jenis-jenis tumbuhan yang digunakan dalam } \\
\text { masakan tradisional Jawa Timur, yaitu urap-urap. Jenis-jenis tumbuhan yang } \\
\text { diidentifikasi diperoleh dari hasil wawancara kepada narasumber (pembuat } \\
\text { urap-urap) dengan menggunakan pedoman wawancara. Identifikasi } \\
\text { tumbuhan dilakukan melalui observasi langsung menggunakan lembar } \\
\text { observasi dan hasil identifikasi dibandingkan dengan referensi ilmiah. Data } \\
\text { yang terkumpul dianalisis secara deskriptif kualitatif. Hasil penelitian } \\
\text { menunjukkan ada } 13 \text { jenis tumbuhan yang teridentifikasi dalam masakan } \\
\text { tradisional urap-urap yaitu empat jenis termasuk kelas Monocotyledonae dan } \\
\text { sembilan jenis lainnya adalah anggota kelas Dicotyledonae. Adapun } 13 \text { jenis } \\
\text { tumbuhan tersebut antara lain: Allium cepa, Allium sativum, Capsicum } \\
\text { anuum, Capsicum frutescens, Citrus hystrix, Vigna radiata, Vigna sinensis, } \\
\text { Ipomoea reptans, Cocos nucifera, Ocimum sanctum, Kaempferia galanga, } \\
\text { Cucumis sativus, dan Carica papaya. Simpulan penelitian ini adalah telah } \\
\text { teridentifikasi } 13 \text { jenis tumbuhan yang terdapat dalam masakan tradisional } \\
\text { Jawa Timur urap-urap yaitu tumbuhan kelas kelas Monocotyledonae dan } \\
\text { Dicotyledonae. } \\
\text { Kata kunci: Masakan tradisional, taksonomi tumbuhan }\end{array}$ \\
\hline
\end{tabular}

This Edubiotik: Jurnal Pendidikan, Biologi dan Terapan is licensed under a CC BY-SA (Creative Commons Attribution-ShareAlike 4.0 International License) 


\section{PENDAHULUAN}

Indonesia merupakan negara megabiodiversitas yang memiliki keragaman budaya dan kearifan lokal yang sangat melimpah. Kekayaan ini penting untuk pembangunan Indonesia yang berkelanjutan (Iskandar, 2016). Perkembangan zaman menjadi ancaman terhadap kelestarian sumber daya hayati, budaya dan kearifan lokal di Indonesia. Pelestarian keanekaragaman hayati di Indonesia saat ini perlu untuk dilakukan dengan cara mengintegrasikan kearifan lokal masyarakat setempat dalam mengelola lingkungan (Kelana, Hidayat, \& Widodo, 2016). Kegiatan eksplorasi tumbuhan dengan memperhatikan keterkaitannya dengan kearifan lokal merupakan obyek kajian etnobotani (Zulharman, Yanuwiadi, \& Batoro, 2015).

Salah satu bentuk kearifan lokal yang erat kaitannya dengan kehidupan masyarakat adalah masakan tradisional (Tyas, 2017). Ada berbagai tumbuhan yang digunakan dalam masakan tradisional. Masakan tradisional yang dipilih dalam penelitian ini adalah masakan tradisional Jawa Timur yang dikenal dengan nama Urap-Urap. Masakan ini merupakan menu vegetarian karena hampir seluruh komponen yang ada di dalamnya berupa tumbuhan.

Pembeda penelitian ini dengan penelitian terdahulu adalah sebebagai berikut. Hasil penelitian Susiarti \& Setyowati (2005) menunjukkan adanya pemanfaatan tumbuhan sebagai bahan rempah tradisional utnuk penyedap masakan di Masyarakat Dayak Kenyah Kalimantan Timur seperti Albertisia papuana Becc., Hodgsonia macrocarpa (BI.) Cogn.), Aleurites moluccana (L.) Willd., Pangium edule Reinw., Ricinus communis L., dan Sumbaviopsis albicans (Blume) J.J.Sm. Penelitian tersebut hanya terfokus pada tumbuhan lokal yang dapat digunakan sebagai bahan penyedap masakan yang ada di Masyarakat Dayak Kenyah Kalimantan Timur. Sedangkan pada penelitian ini, tanaman yang akan diidentifikasi adalah tanaman yang dimanfaatkan sebagai masakan tradisional urap-urap di Jawa Timur khususnya Kabupaten Jombang. Selain itu pada penelitian terdahulu, tumbuhan yang ditemukan dibuat herbarium dan akan dibandingkan dengan spesimen Herbarium BogorienseLIPI di Bogor untuk mengetahui daerah penyebarannya. Akan tetapi, pada penelitian ini mengunakan teknik identifikasi yang berbeda yaitu dengan menggunakan buku referensi ilmiah untuk menentukan morfologi tumbuhan yang telah ditemukan.

Berdasarkan penjelasan di atas, maka identifikasi tumbuhan yang digunakan dalam pembuatan masakan tradisional urap-urap belum pernah dilakukan. Hasil identifikasi ini nantinya digunakan sebagai bahan untuk mengembangkan media pembelajaran dalam bentuk buku referensi taksonomi tumbuhan. Buku referensi merupakan sumber belajar yang efektif untuk memahami informasi yang bersifat umum maupun bidang keilmuan tertentu (Piranti \& Muliyati, 2016). Dengan demikian, penelitian ini bertujuan untuk mengidentifikasi berbagai jenis tumbuhan yang digunakan dalam masakan tradisional Jawa Timur yaitu urap-urap.

\section{METODE PENELITIAN}

Penelitian ini adalah penelitian eksplorasi yang dilakukan di Kabupaten Jombang, Provinsi Jawa Timur, pada bulan April 2019. Sampel maskan tradisional yang dipilih untuk penelitian adalah urap-urap. Teknik pengumpulan data dilakukan sebagai berikut. (1) Wawancara kepada tiga orang narasumber pembuat urap-urap 
dengan menggunakan pedoman wawancara. (2) Pengumpulan tumbuhan yang digunakan dalam pembuatan urap-urap. (3) Identifikasi ciri morfologi tumbuhan yang dikumpulkan melalui observasi langsung dengan menggunakan lembar observasi. (4) Studi pustaka untuk memastikan ciri morfologi dan nama ilmiah tumbuhan yang dikumpulkan dengan menggunakan buku referensi morfologi tumbuhan karya Tjirosoepomo (2013). Data yang diperoleh selanjutnya dianalisis secara deskriptif kualitatif.

\section{HASIL PENELITIAN DAN PEMBAHASAN}

Hasil wawancara yang dilakukan kepada tiga narasumber menunjukkan bahwa tumbuhan yang biasa digunakan dalam pembuatan Urap-Urap antara lain: bawang merah, bawang putih, cabai merah, cabai rawit, jeruk purut, kacang hijau, kacang panjang, kangkung, kelapa, kemangi, kencur, mentimun, dan pepaya. Hasil identifikasi ciri morfologi tumbuhan yang digunakan dalam masakan urap-urap dapat dilihat pada Tabel 1.

Tabel 1. Hasil Identifikasi Ciri Morfologi Tumbuhan yang Digunakan dalam Masakan Urap-Urap

\begin{tabular}{|c|c|c|c|c|}
\hline No. & $\begin{array}{l}\text { Nama } \\
\text { Lokal }\end{array}$ & $\begin{array}{c}\text { Nama } \\
\text { Spesies }\end{array}$ & Kelas & Ciri Morfologi \\
\hline 1 & $\begin{array}{l}\text { Bawang } \\
\text { Merah }\end{array}$ & Allium cepa & Monocotyledonae & $\begin{array}{l}\text { Akar serabut; batang berbentuk cakram } \\
\text { yang ditumbuhi pelepah-pelepah daun } \\
\text { hingga membentuk batang semu yang } \\
\text { berupa umbi lapis; daun tunggal berbentuk } \\
\text { silindris, ujung runcing, berwarna hijau, } \\
\text { melekat pada batang semu; bunga } \\
\text { majemuk dengan benang sari dan putik } \\
\text { pada satu bunga; buah berbentuk bulat } \\
\text { dengan 2-3 butir biji pipih di dalamnya. }\end{array}$ \\
\hline 2 & $\begin{array}{l}\text { Bawang } \\
\text { Putih }\end{array}$ & $\begin{array}{l}\text { Allium } \\
\text { sativum }\end{array}$ & Monocotyledonae & $\begin{array}{l}\text { Akar serabut; batang berbentuk cakram } \\
\text { yang ditumbuhi pelepah-pelepah daun } \\
\text { hingga membentuk batang semu dan umbi } \\
\text { yang berbentuk siung; daun tunggal } \\
\text { berbentuk pita pipih, ujung meruncing, tepi } \\
\text { rata; bunga majemuk dan jarang terbentuk } \\
\text { karena dapat mengganggu pembentukan } \\
\text { umbi. }\end{array}$ \\
\hline 3 & $\begin{array}{l}\text { Cabai } \\
\text { Merah }\end{array}$ & $\begin{array}{l}\text { Capsicum } \\
\text { annuum }\end{array}$ & Dicotyledonae & $\begin{array}{l}\text { Akar tunggang; batang berbentuk bulat } \\
\text { hingga persegi, membentuk percabangan; } \\
\text { daun tunggal berbentuk bulat telur hingga } \\
\text { lanset, ujung runcing, tepi rata, pangkal } \\
\text { runcing, berwarna hijau, pertulangan } \\
\text { menyirip, tangkai menempel pada cabang } \\
\text { dengan letak tersebar; bunga tunggal } \\
\text { berbentuk bintang, tumbuh pada ketiak } \\
\text { daun, mahkota berwarna putih, memiliki } \\
\text { benang sari dan putik dalam satu bunga; } \\
\text { buah berbentuk silindris memanjang, } \\
\text { berukuran } \pm 12 \mathrm{~cm} \text {, ujung runcing, posisi } \\
\text { menggantung pada tangkainya, berwarna } \\
\text { hijau gelap saat muda dan merah terang } \\
\text { saat tua, memiliki rasa yang tidak terlalu } \\
\text { pedas; biji berwarna putih kekuningan, } \\
\text { pipih, berdiameter } 3-5 \mathrm{~mm} \text {. }\end{array}$ \\
\hline 4 & $\begin{array}{l}\text { Cabai } \\
\text { Rawit }\end{array}$ & $\begin{array}{l}\text { Capsicum } \\
\text { frutescens }\end{array}$ & Dicotyledonae & $\begin{array}{l}\text { Akar tunggang; batang berbentuk bulat } \\
\text { hingga persegi, membentuk percabangan; }\end{array}$ \\
\hline
\end{tabular}




\begin{tabular}{cccc}
\hline No. & $\begin{array}{c}\text { Nama } \\
\text { Lokal }\end{array}$ & $\begin{array}{c}\text { Nama } \\
\text { Spesies }\end{array}$ & Kelas \\
\hline & & \\
& & \\
& & & \\
& & & \\
5 & & & \\
& & & \\
Jeruk & Citrus hystrix & Dicotyledonae \\
& &
\end{tabular}
runcing, pangkal runcing, tepi rata atau bergelombang, berwarna hijau, pertulangan menyirip, tangkai menempel pada cabang dengan letak tersebar; bunga tunggal berbentuk bintang, tumbuh pada ketiak daun, mahkota berwarna putih kehijauan, memiliki benang sari dan putik dalam satu bunga; buah berbentuk silindris memanjang, berukuran $\pm 5 \mathrm{~cm}$, ujung runcing, berwarna hijau saat muda dan merah jingga saat tua, memiliki rasa pedas yang lebih tinggi dibandingkan cabai merah; biji berwarna putih kekuningan, berbentuk bulat pipih, diameter 2-3 $\mathrm{mm}$.

Purut

Akar tunggang; batang berbentuk silinder, memiliki garis-garis putih vertikal dan duri besar yang tersebar di permukaannya, bercabang; daun majemuk menyirip beranak daun satu, tangkai daun melebar menyerupai helai daun, helai daun berbentuk bulat telur hingga lonjong, pangkal tumpul, ujung tumpul hingga meruncing, tepi beringgit, berwarna hijau, pertulangan menyirip, beraroma harum jika diremas; bunga tunggal berbentuk bintang, tumbuh pada ujung batang, mahkota berwarna putih kemerahan atau kekuningan, memiliki benang sari dan putik dalam satu bunga; buah berbentuk bulat, permukaan bergelombang dan berbenjolbenjol, berwarna hijau saat muda dan kekuningan saat tua, berasa asam dengan sedikit pahit; biji berbentuk oval, berwarna putih kehijauan, berdiameter 4-6 mm.

Akar tunggang, cabang akar membentuk bintil; batang berbentuk persegi hingga bulat, memiliki rambut-rambut halus pada permukaannya, bercabang; daun majemuk dengan 3 helai anak daun, helai daun berbentuk oval asimetris, ujung runcing, pangkal runcing, pertulangan daun menyirip; bunga berbentuk kupu-kupu, berwarna kuning, tumbuh pada ketiak daun, memiliki benang sari dan putik dalam satu bunga; buah berbentuk polong dengan panjang 6-15 cm, berwarna hijau saat muda dan hitam saat tua; biji berbentuk bulat lonjong, berwarna hijau, berdiameter $\pm 3 \mathrm{~mm}$, berjumlah $6-16$ butir dalam setiap polong.

7 Kacang Vigna Dicotyledonae Akar tunggang, cabang akar membentuk Panjang sinensis bintil; batang berbentuk bulat dengan garisgaris vertikal yang tampak jelas, membelit penopang berlawanan arah jarum jam; daun majemuk dengan 3 helai anak daun, helai daun berbentuk tombak asimetris, ujung runcing, pangkal runcing, tepi rata, permukaan atas kasar; bunga berbentuk kupu-kupu, berwarna kuning, tumbuh pada 


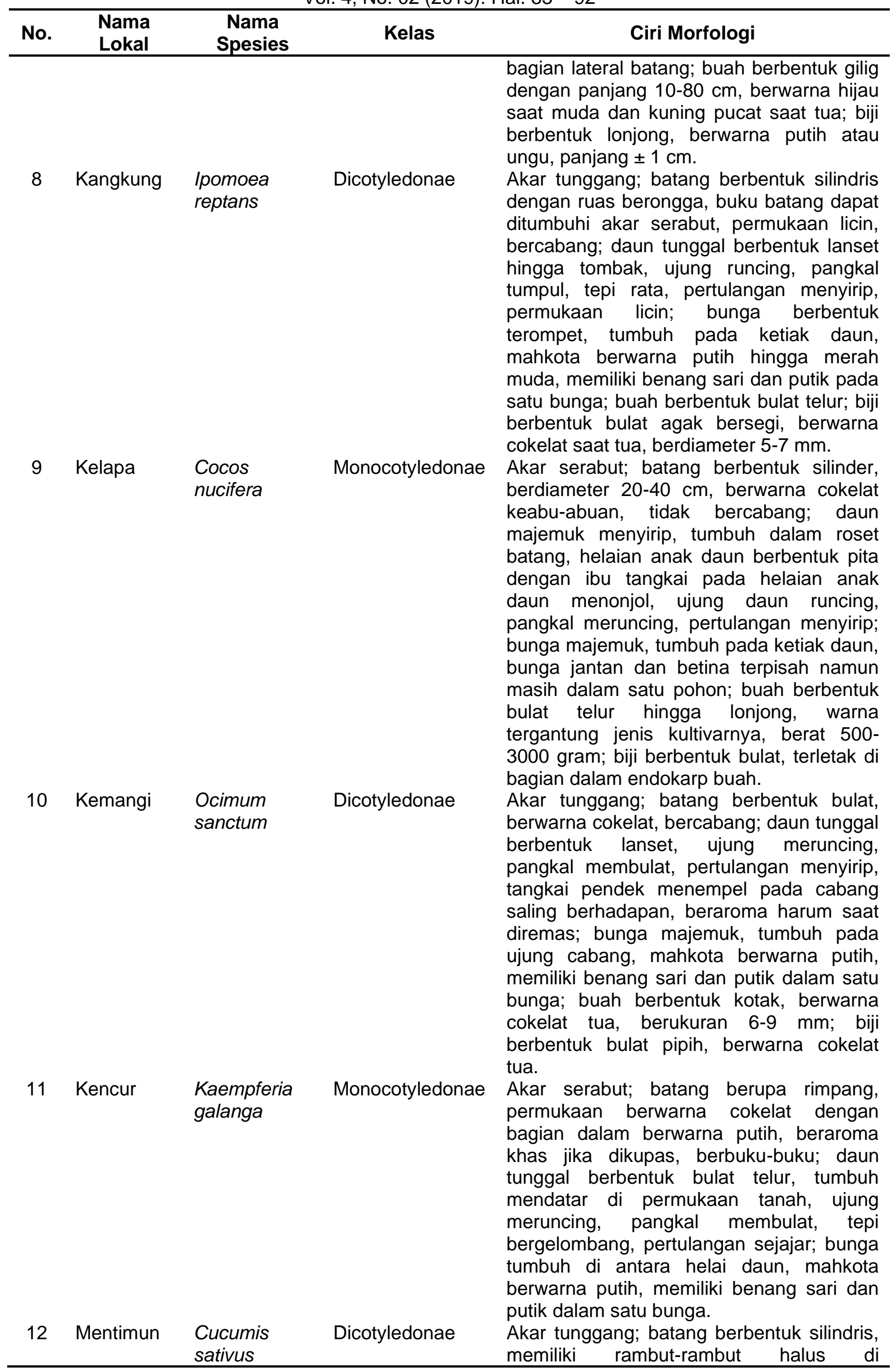




\begin{tabular}{|c|c|c|c|c|}
\hline No. & $\begin{array}{l}\text { Nama } \\
\text { Lokal }\end{array}$ & $\begin{array}{c}\text { Nama } \\
\text { Spesies }\end{array}$ & Kelas & Ciri Morfologi \\
\hline 13 & Pepaya & $\begin{array}{l}\text { Carica } \\
\text { papaya }\end{array}$ & Dicotyledonae & $\begin{array}{l}\text { permukaannya, bercabang, memiliki sulur; } \\
\text { daun tunggal berbentuk bulat berlekuk } \\
\text { hingga bercangap, ujung runcing, pangkal } \\
\text { berlekuk, tepi bergerigi, memiliki rambut- } \\
\text { rambut halus pada permukaannya; bunga } \\
\text { berbentuk terompet, tumbuh pada ketiak } \\
\text { daun, mahkota berwarna kuning, memiliki } \\
\text { benang sari dan putik dalam satu bunga; } \\
\text { buah berbentuk bulat lonjong, panjang } 16- \\
25 \mathrm{~cm} \text {, warna bergantung kultivarnya, } \\
\text { terdapat bintik-bintik menonjol saat muda } \\
\text { dan berangsur menghilang saat tua; biji } \\
\text { berbentuk oval, berwarna putih, diselaputi } \\
\text { lendir, melekat pada ruang-ruang biji. } \\
\text { Akar tunggang; batang berbentuk silinder, } \\
\text { berwarna putih kehijauan, bercabang, } \\
\text { berongga; daun tunggal berbentuk bulat } \\
\text { berbagi menjari, bertangkai panjang } \\
\text { menempel pada batang dalam bentuk } \\
\text { spiral, ujung meruncing, tepi bergerigi } \\
\text { ganda, pertulangan menjari; bunga } \\
\text { berbentuk tunggal, terpisah antara bunga } \\
\text { jantan dan bunga betina; buah berbentuk } \\
\text { bulat lonjong, berwarna hijau saat muda } \\
\text { dan kemerahan hingga jingga saat tua; biji } \\
\text { berbentuk bulat, berwarna putih saat muda } \\
\text { dan hitam saat tua, berdiameter } 4-5 \text { mm. }\end{array}$ \\
\hline
\end{tabular}

Tabel 1 di atas menunjukkan bahwa terdapat 13 macam tumbuhan yang telah teridentifikasi dalam masakan tradisional urap-urap. empat tumbuhan tergolong kelas Monocotyledonae seperti bawang merah, bawang putih, kelapa, dan kencur. sembilan tumbuhan yang lainnya digolongkan ke dalam kelas Dicotyledonae yaitu cabai merah, cabai rawit, jeruk purut, kacang hijau, kacang panjang, kangkung, kemangi, mentimun, dan pepaya.

Tumbuhan yang digunakan dalam proses pembuatan urap-urap dapat dikelompokkan menjadi dua, yaitu tumbuhan sebagai bumbu dan tumbuhan sebagai bahan isian. Tumbuhan yang digunakan sebagai bumbu adalah bawang merah, bawang putih, cabai merah, cabai rawit, jeruk purut, kelapa, dan kencur. Bagianbagian yang digunakan dari tujuh jenis tumbuhan tersebut adalah umbi lapis bawang merah, umbi bawang putih, buah cabai merah dan buah cabai rawit yang telah masak (berwarna merah), daun jeruk purut, daging buah kelapa, dan rimpang kencur. Adapun tumbuhan yang digunakan sebagai bahan isian adalah kacang hijau, kacang panjang, kangkung, kemangi, mentimun, dan pepaya. Bagian-bagian yang digunakan dari enam jenis tumbuhan tersebut adalah tunas kacang hijau (taoge), buah muda kacang panjang, daun dan batang kangkung, daun kemangi, buah muda mentimun, dan daun pepaya.

Bawang merah dan bawang putih merupakan anggota genus Allium yang memang telah umum digunakan sebagai bumbu masakan. Bagian tumbuhan yang biasa digunakan sebagai bumbu adalah umbinya. Umbi lapis bawang merah mengandung nutrisi dan senyawa bioaktif yang bermanfaat untuk kesehatan. Nutrisi dalam 100 gram umbi lapis bawang merah segar antara lain: 1,2\% protein; 0,1\% 
lemak, $0,4 \%$ serat; $0,6 \%$ mineral, $47 \mathrm{mg}$ kalsium; $50 \mathrm{mg}$ fosfor; $0,7 \mathrm{mg}$ zat besi; dan $11 \mathrm{mg}$ vitamin C (Kumar, Bhowmik, Chiranjib, Biswajit, \& Tiwari, 2010). Umbi bawang putih juga memiliki khasiat kesehatan, selain sebagai penyedap masakan (Alam, Hoq, \& Uddin, 2016). Bawang putih mengandung organo sulfur (Allicin dan ajoene), minyak atsiri, dan flavonoid yang bersifat anti bakteri (Salima, 2015).

Cabai merah dan cabai rawit tergabung dalam genus yang sama, yaitu genus Capsicum. Bagian tumbuhan cabai yang biasa digunakan sebagai bumbu masakan adalah buahnya, baik yang masih muda maupun yang telah tua. Cabai merah mengandung nutrisi dan senyawa antioksidan yang bermanfaat bagi kesehatan. Senyawa antioksidan yang terkandung dalam cabai merah antara lain: capsaicin, fenol, karotenoid, dan berbagai asam amino (Khan, Mahmood, Ali, Saeed, \& Maalik, 2014). Capsaicin merupakan senyawa yang menyebabkan rasa pedas pada cabai (Al-snafi, 2015). Cabai rawit memiliki rasa yang lebih pedas dibandingkan dengan cabai merah. Pada umumnya, cabai merah digunakan lebih untuk memberikan warna merah pada masakan dibandingkan memberikan rasa pedas.

Jeruk purut merupakan anggota genus Citrus yang sering digunakan bagian daunnya sebagai bumbu masakan. Daun jeruk purut memiliki aroma yang khas yang dapat menambah kelezatan masakan. Daun jeruk purut diketahui mengandung minyak atsiri, flavonoid, saponin, dan steroid (Adrianto, Yotopranoto, \& Hamidah, 2014). Buah jeruk purut memiliki rasa asam yang sedikit pahit, biasanya digunakan sebagai bahan jamu tradisional.

Kelapa memiliki peran yang penting dalam kehidupan masyarakat Indonesia, khususnya dalam berbagai kearifan lokal (Pratiwi \& Sutara, 2013). Buah kelapa yang sesungguhnya merupakan buah keras yang terdiri dari tiga lapisan, yaitu eksokarp, mesokarp, dan endokarp. Di bagian dalam endokarp ini terdapat endosperma yang berbentuk cair saat muda dan memadat saat tua (Tjitrosoepomo, 2009). Endosperma cair biasa dikonsumsi sebagai minuman atau diolah menjadi nata de coco. Endosperma padat yang cukup tebal biasa digunakan sebagai bahan baku santan atau kelapa parut untuk berbagai olahan seperti urap-urap dan serundeng.

Kencur merupakan anggota famili Zingiberaceae yang sering digunakan dalam masakan, berbagai olahan minuman, maupun pengobatan tradisional. Bagian tumbuhan kencur yang sering digunakan adalah rimpangnya. Rimpang kencur memiliki rasa yang cenderung pedas dan aroma yang khas. Rasa dan aroma ini dipengaruhi oleh kandungan senyawa kimia di dalamnya, yaitu etil sinamat, etil pmetoksisinamat, p-metoksostiren, borneol, dan minyak atsiri (Prabawati \& Pujimulyani, 2018).

Kacang hijau dan kacang panjang tergabung dalam genus yang sama, yakni genus Vigna. Akar kedua tumbuhan ini membentuk bintil-bintil akar yang merupakan bentuk simbiosis mutualisme dengan bakteri Rhizobium sp. Bagian tumbuhan kacang hijau yang digunakan dalam Urap-Urap adalah tunasnya, atau sering disebut taoge oleh masyarakat umum. Taoge kacang hijau mengandung banyak nutrisi yang penting bagi kesehatan, seperti vitamin E, flavonoid, dan senyawa fenol (Asrullah, 2015). Bagian tumbuhan kacang panjang yang biasa digunakan sebagai isian urapurap adalah buah mudanya. Buah muda kacang panjang memiliki kandungan vitamin 
$A$, vitamin $B$, vitamin $C$, mineral, protein, lemak, dan karbohidrat sehingga baik untuk kesehatan (Simarmata, Ardian, \& Sa'diyah, 2015).

Kangkung merupakan sayuran hijau yang banyak dikonsumsi masyarakat Indonesia. Kandungan nutrisi yang cukup tinggi dan harga relatif murah menjadikan kangkung sebagai sayuran favorit berbagai lapisan masyarakat (Ridwan, Hastuti, \& Prabowo, 2014). Bagian tanaman kangkung yang digunakan dalam urap-urap adalah daun beserta tangkainya dan batang yang dekat ujung. Kangkung mengandung air, protein, lemak, karbohidrat, kalsium, potasium, zat besi, vitamin C, vitamin A, dan vitamin B (Wibowo \& Sitawati, 2017). Kandungan zat besi dalam kangkung dapat mencegah anemia bagi konsumennya.

Kemangi biasa dikonsumsi mentah sebagai lalapan oleh masyarakat Indonesia, atau digunakan sebagai penyedap dalam masakan. Bagian yang sering digunakan adalah daunnya. Daun kemangi mengandung minyak atsiri dan senyawa bioaktif lain yang bersifat imunomodulator dan antimikroba (Bhatt, 2015). Mentimun merupakan anggota famili Cucurbitaceae yang banyak dimanfaatkan buah mudanya sebagai sayuran segar maupun diawetkan. Buah mentimun muda digunakan dalam bentuk segar dalam urap-urap. Olahan lain adalah acar mentimun, dimana buah muda direndam dalam larutan cuka berbumbu sehingga lebih lama disimpan. Buah mentimun banyak mengandung air, nutrisi, dan senyawa bioaktif yang bersifat antioksidan dan antimikroba (Foong, Mohammad, \& Ichwan, 2015).

Pepaya merupakan salah satu tumbuhan buah yang banyak dibudidayakan oleh masyarakat Indonesia. Bagian tumbuhan pepaya yang digunakan dalam urapurap adalah daunnya. Daun pepaya memiliki rasa pahit yang disebabkan oleh adanya kandungan enzim endopeptidase (Sudhakar \& Theivanai, 2014). Masyarakat di Jawa Timur menggunakan tanah liat dan air kapur saat merebus daun pepaya untuk mengurangi rasa pahitnya. Daun pepaya juga sering digunakan dalam pengobatan tradisional sebagai anti demam. Ekstrak daun papaya juga memiliki sifat bakteriostatik terhadap bakteri Eschericia coli dan Salmonella thypi (Sudarwati, 2018).

Pada satu jenis masakan tradisional teridentifikasi 13 spesies tumbuhan dengan berbagai ciri morfologi dan khasiatnya. Hal ini membuktikan eratnya kehidupan manusia dengan sumber daya alam, khususnya tumbuhan. Kewajiban untuk melestarikan kekayaan alam Indonesia ini menjadi tugas setiap warga negara, terlebih para generasi muda. Penyampaian informasi dan pengetahuan tentang pentingnya pelestarian tumbuhan dan kearifan lokal bangsa Indonesia perlu dilakukan sedini mungkin dan seintensif mungkin. Salah satu media yang dapat dipilih untuk mewujudkan hal tersebut adalah buku referensi. Buku merupakan salah satu sumber informasi yang efektif. Oleh karena itu, hasil penelitian ini nantinya akan digunakan sebagai bahan penyusunan buku referensi taksonomi tumbuhan berbasis kearifan lokal.

\section{SIMPULAN DAN SARAN}

Terdapat 13 jenis tumbuhan dalam masakan tradisional Jawa Timur diantaranya sebagai berikut. (1) Bawang merah (Allium cepa). (2) Bawang putih (Allium sativum). (3) cabai merah (Capsicum anuum). (4) Cabai rawit (Capsicum 
frutescens). (5) Jeruk purut (Citrus hystrix). (6) Kacang hijau (Vigna radiata). (7) Kacang panjang (Vigna sinensis). (8) Kangkung (Ipomoea reptans). (9) Kelapa (Cocos nucifera). (10) Kemangi (Ocimum sanctum). (11) Kencur (Kaempferia galanga). (12) Mentimun (Cucumis sativus). (13) Pepaya (Carica papaya). Perlu adanya kksplorasi lebih lanjut pada jenis-jenis tanaman yang digunakan dalam masakan tradisional lainnya di Jawa Timur. Informasi dan pengetahuan ini nantinya dapat digunakan sebagai bahan untuk mengembangkan media informasi berupa buku referensi taksonomi tumbuhan melalui penelitian pengembangan ( $\& D)$.

\section{UCAPAN TERIMA KASIH}

Ucapan terima kasih disampaikan kepada para narasumber dan pembantu peneliti serta Kementerian Riset Teknologi dan Pendidikan Tinggi Republik Indonesia yang telah memberikan dana penelitian.

\section{RUJUKAN}

Adrianto, H., Yotopranoto, S., \& Hamidah. (2014). Effectivity of Kaffir lime (Citrus hystrix), Nasnaran Mandarin (Citrus amblycarpa), and Pomelo (Citrus maxima) Leaf Extract Against Aedes aegypti Larvae. Aspirator, 6(1), 1-6. Retrieved from http://ejournal.litbang.depkes.go.id/index.php/aspirator/article/view/3516

Alam, M. K., Hoq, M. O., \& Uddin, M. S. (2016). Medicinal plant Allium sativum = A Review. Journal of Medicinal Plants Studies JMPS, 72(46), 72-79. Retrieved from http://www. plantsjournal.com/archives/?year=2016\&vol=4\&issue=6\&part= B\&Articleld $=463$

Al-snafi, A. E. (2015). The Pharmacological Importance of Capsicum Species (Capsicum annuum and Capsicum frutescens) Grown in Iraq. Journal of Pharmaceutical Biology, 5(3), 124-142. Retrieved from https://www.semantic scholar.org/

Asrullah, M. (2015). Kecambah Kacang Hijau Dan Efikasinya Terhadap Kesehatan. Bimgi, 3(2), 30-35. Retrieved from https://issuu.com/bimkes/docs/bimgi_ vol_3_no_2

Bhatt, K. J. (2015). Ocimum Sanctum: The Indian Medicinal plant. International Journal of Chemtech Applications, 3(1), 53-57. Retrieved from https://www.researchgate.net/directory/publications

Foong, F. H. N., Mohammad, A., \& Ichwan, S. J. A. (2015). Biological properties of cucumber (Cucumis sativus L.) extracts. Malaysian Journal of Analytical Sciences, 19(6), 1218-1222. Retrieved from http://www.ukm.my/mjas/mjas2018/

Iskandar, J. (2016). Etnobiologi dan Keragaman Budaya di Indonesia. Indonesian Journal of Anthropology, 1(1), 27-42. https://doi.org/10.24198/umbara.v1i1.9602

Kelana, H. W., Hidayat, T., \& Widodo, A. (2016). Pewarisan Pengetahuan dan Keterampilan Identifikasi Keanekaragaman Tanaman Padi Lokal pada Generasi Muda Kasepuhan Adat Banten Kidul. In Proceeding Biology Education Conference (Vol. 13, pp. 255-262). Retrieved from https://jurnal.uns.ac.id/ prosbi/\%20article/view/5712

Khan, F. A., Mahmood, T., Ali, M., Saeed, A., \& Maalik, A. (2014). Pharmacological importance of an ethnobotanical plant: Capsicum annuum L. Natural Product Research: Formerly Natural Product Letters, 28(16), 1267-1274. https://doi.org/10.1080/14786419.2014.895723

Kumar, K. P. S., Bhowmik, D., Chiranjib, Biswajit, \& Tiwari, P. (2010). Allium cepa: A traditional medicinal herb and its health benefits. Journal of Chemical and 
Pharmaceutical Research, 3(4), 773-776. Retrieved from http://www.jocpr.com/ abstract/allium-cepa-a-traditional-medicinal-herb-and-its-health-benefits-44.html

Piranti, L., \& Muliyati, D. (2016). Pengembangan Buku Referensi Berbasis Multi Representasi dengan Pendekatan Kontekstual pada Materi Kalor dan Termodinamika. In SNIPS 2016 (pp. 495-300). Retrieved from http://portal. fmipa.itb.ac.id/snips2016/kfz/files/snips_2016_lindrie_piranti_06ff3f8deb88dfabc 74762237984ff6f.pdf

Prabawati, T. P., \& Pujimulyani, D. (2018). Pengaruh Penambahan Ekstrak Kencur (Kaempferia galanga). In Seminar Nasional Inovasi Pangan Lokal untuk Mendukung Ketahanan Pangan 2018 (pp. 209-216). Yogyakarta. Retrieved from http://ejurnal.mercubuana-yogya.ac.id/index.php/Prosiding_IPPL/article/ view/731

Pratiwi, F. M., \& Sutara, P. K. (2013). Etnobotani kelapa (Cocos nucifera L.) Di Wilayah Denpasar dan Badung. Jurnal Simbiosis, 1(2), 102-111. Retrieved from https://ojs.unud.ac.id/index.php/simbiosis/article/view/7713/5802

Ridwan, Hastuti, D., \& Prabowo, R. (2014). Analisis Pendapatan Petani Kangkung Darat (Ipomea Reptans Poir) Tradisional. Mediagro, 10(2), 81-89. Retrieved from https://publikasiilmiah.unwahas.ac.id/index.php/Mediagro/article/download $/ 1591 / 1671$

Salima, J. (2015). Antibacterial Activity Of Garlic (Allium sativum I .). Jurnal Majority, 4(2), 30-39. Retrieved from http://juke.kedokteran.unila.ac.id/index.php/ majority/article/view/523

Simarmata, E. R., Ardian, \& Sa'diyah, N. (2015). Penampilan Karakter Produksi Kacang Panjang (Vigna sinensis L.) Generasi F1 Dan Tetuanya. Jurnal Agrotek Tropika, 3(3), 303-308. Retrieved from http:/jurnal.fp.unila.ac.id/index.php/JA /article/view/1950

Sudarwati, T. P. L. (2018). Aktivitas Antibakteri Daun Pepaya (Carica Papaya) Menggunakan Pelarut Etanol Terhadap Bakteri Bacillus subtilis. Journal of Pharmacy and Science, 3(2), 13-16. Retrieved from https://www.akfarsurabaya .ac.id/ejournal/index.php/jps/article/view/105

Sudhakar, N., \& Theivanai, V. R. (2014). Potential medicinal properties of Carica papaya Linn. Int $J$ Pharm Pharm Sci, 6(2), 2-5. Retrieved from https://www.semanticscholar.org/

Susiarti, S., \& Setyowati, F. M. (2005). Bahan Rempah Tradisional dari Masyarakat Dayak Kenyah di Kalimantan Timur. BIODIVERSITAS (Journal of Biological Diversity), 6(4), 285-287. https://doi.org/10.13057/biodiv/d060415

Tjitrosoepomo, G. (2009). Morfologi Tumbuhan. Yogyakarta: Gadjah Mada University Press. ISBN: 978-979-420-241-8

Tyas, A. S. P. (2017). Identifikasi Kuliner Lokal Indonesia dalam Pembelajaran Bahasa Inggris. Jurnal Pariwisata Terapan, 1(2), 38. https://doi.org/10.22146/jpt.24970

Wibowo, H. Y., \& Sitawati. (2017). Respon Tanaman Kangkung Darat (Ipomoea Reptans Poir) Dengan Interval Penyiraman Pada Pipa Vertikal Respons Of Kangkong (Ipomoea reptans Poir) Watering Interval On. Plantropica, 2(2), 148154. Retrieved from https://jpt.ub.ac.id/ index.php/jpt/article/view/142

Zulharman, Yanuwiadi, B., \& Batoro, J. (2015). Etnobotani Tumbuhan Obat dan Pangan Masyarakat Suku Sambori Kabupaten Bima Nusa Tenggara Barat Indonesia. Natural-B, 3(2), 198-204. http://dx.doi.org/10.21776/ub.naturalb.2015.003.02.15 